\title{
Effect of n-butanol fuel additive to methanol-gasoline blend on combustion and emission characteristics in a single cylinder spark ignition engine
}

\begin{abstract}
In order to reduce the effect of emissions on the environment by burning petroleum oil in engines, researchers have sought out one of the solutions to be the blending of oxygenated additives with the fossil fuels. In this study n-butanol was added to a blend of methanol-gasoline fuel. The effects on Combustion and emission are reported using a single cylinder Octane rating BASF internal combustion engine. The results obtained indicated that the combustion duration reduced with increased shared volume of n-butanol in the methanol-gasoline blends. The blends used were M10, $(10 \%$ methanol 90\% gasoline by volume), M10:20 (10\% methanol, 20\% n-butanol, $70 \%$ gasoline), M20:30, M80:10. The peak pressure increased with the methanol fraction in the blend with gasoline. Unburned hydrocarbon (UHC) emissions reduced with $\mathrm{m} 80$ to about $300 \mathrm{ppm}$ and reduced even further with $10 \% \mathrm{n}$-butanol added to $\mathrm{m} 80$ showing that $\mathrm{n}$-butanol has the effect of reducing UHC emissions when methanol fraction is above $20 \%$ in gasoline. As n-butanol was increased further by $30 \%$ in $\mathrm{m} 20$ (M20:30), Nox concentration did not change significantly when comparing values with the blends of $\mathrm{m} 10$ and M10:20
\end{abstract}

Keywords: n-butanol, methanol, gasoline, combustion, emission, spark ignition engine
Volume 3 Issue 3 - 2018

\author{
Lennox Siwale,' Akos Bereczky² \\ 'Copperbelt University, Zambia \\ ${ }^{2}$ Department of Energy Engineering, Budapest University of \\ Technology and Economics, Hungary
}

Correspondence: Lennox Siwale, Copperbelt University, Zambia, Tel +27764422347, Email zumbe.siw@gmail.com

Received: March 31, 2018 | Published: May 18, 2018

\section{Introduction}

The efforts of researchers world-wide have been and continue to be directed towards finding fuels that are cleaner than fossil fuels in internal-combustion engines. The goal is to replace or reduce the use of petroleum oil because conventional fuels such as gasoline degrade the environment. Use of petroleum oil in transportation greatly contributes to the deterioration of the environment through the emission of regulated emissions such as nitrogen oxides $\left(\mathrm{NO}_{\mathrm{x}}\right)$, unburned hydrocarbon (UHC), carbon monoxide (CO), particulate matter $(\mathrm{PM})$ and carbon dioxide $\left(\mathrm{CO}_{2}\right.$. The $\mathrm{CO}_{2}$ pollutant accumulating into the atmosphere contributes to the greenhouse gases (GHG) effect, global warming and climate change. Unburned hydrocarbon and soot cause respiratory problems and are carcinogenic. Oxygenated fuels such as alcohols have been used extensively by researchers worldwide to reduce the negative effects on the environment by burning petroleum oil.

In their studies of combustion of n-butanol-gasoline blends ${ }^{1}$ observed that the cylinder pressure was lowest for gasoline but increased with content of n-butanol in gasoline or volume ratio of butanol in gasoline: $20 \%$ butanol (B20), B60 and B100. The experiments were conducted on a 4-cylinder 1.6 L spark ignition engine with compression ratio (CR) 9.6. It was reported $b^{2}$ that ignition timing parameter has a significant effect on the performance of Spark Ignition engines. In their studies for lean mixtures retarding the ignition timing decreases the peak pressure and temperature inside the cylinder during combustion leaving less time available for complete combustion. ${ }^{3}$ reported that peak indicated mean effective pressure (IMEP) for 30\% butanol-gasoline at equivalent ratio $\phi=1.1$ is higher than (IMEP) for $30 \%$ methanol-gasoline.
The study of engine performance is not new. Equations used to calculate engine performance are well documented in literature. ${ }^{4-6}$ it was reported ${ }^{7}$ that the accumulation of the heat release due to the changes of the physical, and chemical properties of the fuel affect the emission and thermal efficiency. An excessively late Crank Angle (CA) results in a lower BTE and causes UHC and CO emissions to deteriorate, due to remarkable heat transfer and incomplete combustion. ${ }^{8}$ Conducted experiments on an SI engine, and found that butanol blends: B20, B40, B60 and B80 indicate higher $\mathrm{CO}$ emission concentration than that of GF. Concentration of $\mathrm{CO}$ was the lowest on equivalence ratio near 0.95 for the test fuels. The lowest concentration of $\mathrm{CO}$ was indicated by GF followed by B20, B40, B60, and B80 blends. ${ }^{9}$ reports a lower concentration of $\mathrm{CO}$ emission for $\mathrm{B} 30$ than B50 blends with gasoline. Evaluating the combustion characteristics of butanol/gasoline in spark ignition engines at stoichiometric mixtures, B0, B20 and B40 results obtained in ${ }^{8}$ indicates that all blends yielded the same UHC emission. Further increasing n-butanol in gasoline: B60 and B80 brings UHC emissions level above that of gasoline

Conducted $^{2}$ experiments on a Hydra 4-stroke, single-cylinder, SI engine operating at the steady state. As the fuel-air mixture is weakened, the oxygen concentration increase, thus absorbing energy as diluents thereby reduces the temperature of mixture and $\mathrm{NO}_{x}$, which is temperature dependent. This is evident using 30\% isobutanol-gasoline blend which records lower NOx than GF does. The cited author stated that for a rich mixture, there is little oxygen to dissociate and attach to nitrogen atoms to form $\mathrm{NO}_{\mathrm{x}}$. The author reported that production of NOx in a cylinder is controlled by the fuelair equivalence ratio, maximum cycle temperature and combustion rate or combustion duration during the compression and expansion 
process. In the experiments conducted by, ${ }^{8} \mathrm{NO}_{\mathrm{x}}$ varied as the function of equivalence ratio $\Phi . \mathrm{NO}_{\mathrm{x}}$ reduces with increased fraction of n-butanol in GF. The blends used were B20, B40, B60 and B80. The blend $\mathrm{B} 0$ recorded the highest $\mathrm{NO}_{\mathrm{x}}$ concentration. In the excess-air region, the concentration of nitrogen oxides reduced when the butanol fraction was increased. This trend was similar in the fuel-rich region where the equivalence ratio is greater than 0.95 . This occurs because the evaporative cooling effects (latent heat) of the n-butanol-gasoline mixture or the diluents reduce the combustion chamber's temperature and therefore $\mathrm{No}_{\mathrm{x}}$ concentration is reduced. The effect of $\mathrm{n}$-butanol additive to methanol-gasoline blends on combustion and emission is reported in this study. The good properties of one alcohol for engine performance become the leverage to enhance the undesirable impact of a competing alcohol included in the gasoline blend.

In gasoline engines, biobutanol has been studied and discussed as potential fuel. ${ }^{1,8,10,11}$ A substantial number of studies exist in literature where single alcohols are blended with gasoline to fuel SI engines. ${ }^{12-14}$ However, moderately fewer studies involving combustion characteristics of isomeric butanol and methanol have been reported. ${ }^{1,12,15}$ Most of the studies that have evaluated the potential of alcohol were based on methanol and ethanol. ${ }^{16}$ Alcohols can be promoted as alternative-fuels or alternative-fuel components in transportation for many reasons, including the following:

i. Reduction of greenhouse-gas emission

ii. Enhancement of overall energy-efficiency

iii. Social reasons (e.g. employment in the agricultural sector and utilization of agricultural lands for fuels)

iv. High laminar flame propagation, which shortens and enhances combustion and so improves the BTE of the engine.

v. Lower viscosity of alcohols in comparison with diesel improves injection, atomization and vaporization of the charge.

vi. High evaporative cooling, resulting in cooler intake charge. This raises the volumetric efficiency and reduces the compression work. ${ }^{17}$ some fuel properties of methanol, n-butanol and gasoline are compared in Table1.

Table I Comparison of fuel properties for methanol, n-butanol and gasoline

\begin{tabular}{|c|c|c|c|c|}
\hline & Methanol & Ethanol & Gasoline & *Butanol \\
\hline Molecular formula & $\mathrm{CH}_{3} \mathrm{OH}$ & $\mathrm{C}_{2} \mathrm{H}_{5} \mathrm{OH}$ & - & $\mathrm{C}_{4} \mathrm{H}_{9} \mathrm{OH}$ \\
\hline Oxygen content (\%) & 50 & 46 & 0 & 22 \\
\hline Density $\left[\mathrm{kg} / \mathrm{m}^{3}\right]$ & 792 & 785 & 740 & 810 \\
\hline LHV $[\mathrm{MJ} / \mathrm{kg}]$ & 20 & 26.9 & 44.3 & 33.3 \\
\hline Octane Number & 111 & 108 & $>90$ & 113 \\
\hline $\begin{array}{l}\text { Auto-ignition temp } \\
{\left[{ }^{\circ} \mathrm{C}\right]}\end{array}$ & 465 & 425 & $228-470$ & 385 \\
\hline $\begin{array}{l}\text { Stoichiometric }(\mathrm{A} / \mathrm{F}) \\
\text { ratio[kg/kg] }\end{array}$ & 6.47 & 9.0 & 14.8 & 11.1 \\
\hline Latent heat $[\mathrm{kJ} / \mathrm{kg}]$ & 1103 & 840 & 305 & 581.4 \\
\hline $\begin{array}{l}\text { Vapour pressure at } \\
23.5^{\circ} \mathrm{C}[\mathrm{kPa}]\end{array}$ & 3.2 & - & $60-90$ & 32 \\
\hline
\end{tabular}

*Source: ${ }^{1,21}$
The advantages of methanol in comparison with the properties of ethanol and gasoline ${ }^{18}$ are as follows:

i. Methanol-gasoline blended with a stoichiometric mixture of gasoline has the same lower heating value (LHV). However, more blended fuel is delivered to maintain the same engine power as with gasoline. Experiments show that, if a small fraction of methanol is used in blends of methanol-gasoline, the engine runs stably and successfully.

ii. The engine automatically keeps the air-to-fuel ratio: (A/F) equal to 14.7. This occurs with a lambda closed-loop control, to aid the electronic-control Unit (ECU). Methanol has a higher Research Octane Number (RON). The RON can be increased by using methanol-gasoline blends,

iii. Methanol has a high laminar flame propagation speed: 58 $\mathrm{cm} / \mathrm{s}$ with reference $\mathrm{Tu}$ (unburned gas temperature of $348 \mathrm{~K}$ ); atmospheric pressure, Po of $1 \mathrm{~atm}$ with reference $\lambda$ of $0.9 .{ }^{19}$ this may reduce the combustion duration and improve the engine's thermal efficiency. ${ }^{20,21}$

\section{Objectives}

The general objective is to reduce the negative impacts of petroleum oil based fuels in reciprocating engines on the environment through the use of oxygenated (alcohol) blends, while not deteriorating engine performance. The specific objectives are as follows:

\section{Specific objectives}

i. To compare the combustion and emission characteristics of dual alcohol (methanol n-butanol-gasoline) blends with single alcohol (methanol-gasoline) blends in a single-cylinder spark ignition (SI) engine.

ii. To determine the effect of n-butanol to a single-alcohol blend with gasoline on performance combustion and emission characteristics.

\section{Materials and methods}

The test facility for the single-cylinder SI engine and general schematic layout including control panel, intake, exhaust lines, measuring instruments for emissions concentration, and data collection, processing, and display is as indicated in Figure 1. The single-cylinder, spark ignition octane rating engine used in this study was the BASF (Badische Anilin- und Soda Fabrik). The control panel is shown in Figure 2. The equipment consists of two main parts; the internal combustion engine and the electric motor, which is used to launch the engine. To adjust the compression ratio to 7.3:1, the wheel for adjusting the compression ratio was turned counterclockwise, moving the cylinder of the engine down, and increasing the compression ratio.

The fuel container is lifted by rotating it to fill the carburetor nearly full to a fuel level of maximum 50 divisions etched on the glass scale, or other division depending on the blends. The alcohol-gasoline blends with a higher-alcohol content is required to fill the carburetor to a higher division than blends with a lower-alcohol content because of the lower-energy content of the alcohol blends. The hydrostatic pressure increases the mass-fuel flow into the carburetor or reduces it depending on the level (height) of the fuel in the glass tube. The basic engine parameters are presented in Table 2. The accuracy of measuring instruments is presented in Table 3 . The engine used was a 


\section{Determination of the heat release rate}

The heat release rate is determined by the following Equation (1)

$$
\frac{d Q}{d \theta}=\frac{1}{\gamma-1}\left(\gamma * p \frac{d v}{d \theta}+V \frac{d p}{d \theta}\right)
$$

The term on the left-hand side $\frac{d Q}{d \theta}$ is the heat release rate; and $\gamma$ is the specific heat ratio. On the right hand, $V$ is the instantaneous engine displacement, and $\frac{d p}{d \theta}$ is the change in indicated pressure in the combustion chamber divided by the crank angle change and $\frac{d v}{d \theta}$ is the change in volume divided by the crank angle change. Using a computer model, the heat release was evaluated using the pressure values from the experimentally recorded computer pressure traces and the instantaneous volume evaluated from the following Equation (2):

$$
\frac{d v}{d \theta}=\frac{\pi A}{180} * r\left\{\sin \left(\frac{\pi \theta}{180}\right)+\frac{R^{2} \sin ^{2}\left(\frac{\pi \theta}{180}\right)}{2 * \sqrt{\left(1-R^{2} \sin ^{2}\left(\frac{\pi \theta}{180}\right)\right)}}\right\} \ldots \ldots \ldots
$$

Where $A$ is the cylinder cross-sectional area, the ratio of the connecting rod to radius $(\mathrm{R}=1 / \mathrm{r}), \theta$ is the crank angle, degrees.

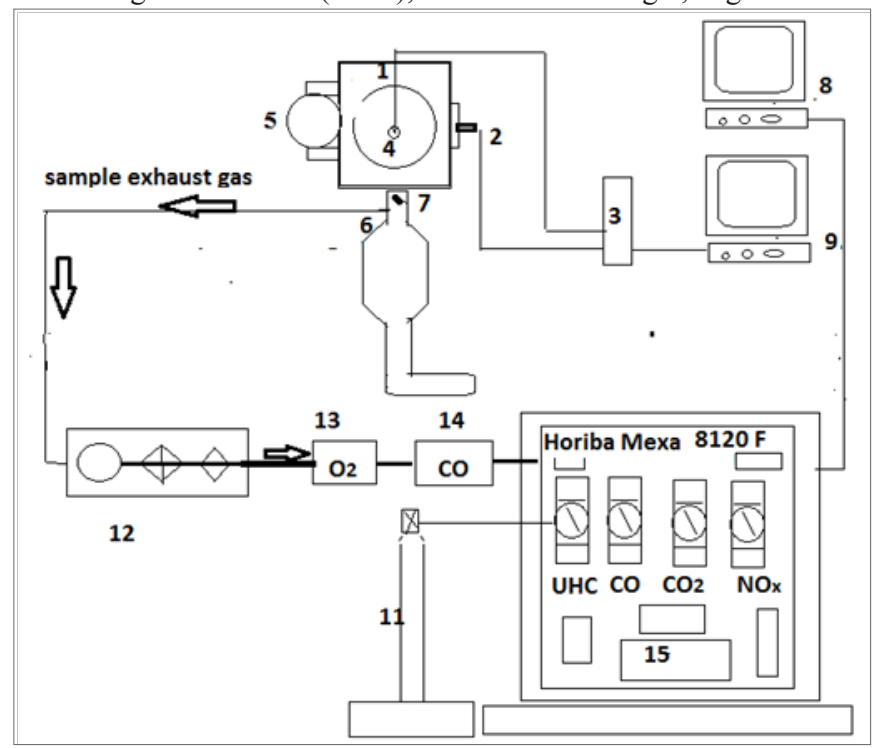

Figure I schematic arrangements of octane test engine and gas analyzers.

Legend(I) Single piston BASF engine, (2) Crank angle optical encoder, (3) Charge amplifier, (4) Piezo-electric pressure transducer, (5) Carburretor, (6) Three-way catalytic converter, (7) Thermocouple, (8) Data acquisition PC to measure emissions, (9) PC to measure indicated pressure, (I I) $\mathrm{H}_{2}-\mathrm{He}$ cylinder, (I2) heated pre-sampler system, (13) Paramagnetic-analyzer $\left(\mathrm{O}_{2}\right)$, (14) Carbon monoxide gas analyzer, (I5) Horiba Mexa 8I20F analyzers

\section{Lower heating value}

The LHV of the blend is given by Equation (3):

$$
L H V_{b l}=\sum_{1}^{2} \frac{v i}{v} * \rho_{i} * L H V_{i} / \sum_{i=1}^{2} \frac{v i}{v} * \rho_{i}
$$

Where $L H V_{b l}$ is the lower heating value $(\mathrm{MJ} / \mathrm{kg})$ of the blend; $L H V_{i}$ is the lower heating value of component, $i$, of the blend, $i=1$ is $\mathrm{n}$-butanol, $\mathrm{i}=2$ is gasoline.

Density of a blend is calculated from the following Equation (4):

$$
\rho=\sum_{i=1}^{2} \frac{v i}{v} * \rho_{i}
$$

Where $\rho$ is the density of the blend $\left(\mathrm{kg} / \mathrm{m}^{3}\right)$ and $v_{i} / v$ is the volume fraction of component $i$ of the blend.

\section{Air-to-fuel ratio}

Equation (5) for the calculation of air-to-fuel ratio is given below:

$$
A / F s_{b l}=\left\{\sum_{i=1}^{2} \frac{v i}{v} * \rho_{i} * A / F s i\right\} / \sum_{i=1}^{2} \frac{v i}{v} * \rho_{i}
$$

Where: $A / F s_{b l}$ is the stoichiometric air-fuel ratio of the blend and $A / F_{s i}$ is the stoichiometric air-fuel ratio for i component of the blend. The calculated properties of the test blends are listed in Table 4.

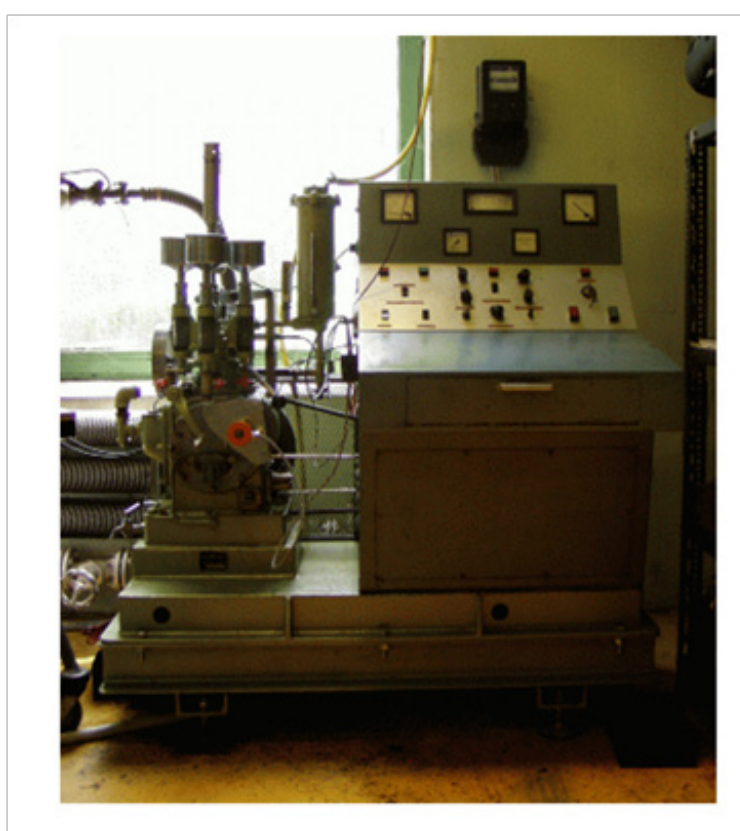

Figure 2 Control panel and BASF octane rating engine.

The unburned hydrocarbon, (UHC), was measured by the hydrocarbon analyzer HORIBA FID-FIA-22, accuracy $\pm 2 \%$ of FSD which is equipped with a heated type flame ionisation detector. Nitrogen oxide (Nox) was measured by analyzer HORIBA Mexa $8120 \mathrm{~F}$. $\mathrm{NO}_{\mathrm{x}}$ was measured by means of a chemiluminescence detector (CLD) of the type CLD-53M, accuracy $\pm 2 \%$ of FSD. The detector allowed the $\mathrm{NO} / \mathrm{NO}_{\mathrm{x}}$ content to be measured in the range 0 and $5000 \mathrm{ppm}$. The in-cylinder pressure was measured by a piezoelectric pressure transducer; and piston speed, (in RPM), and the top dead centre (TDC) were measured by a pick-up sensor crank angle trigger/ Octane rating engine type Kübler 8.5822.3851.1024, 1024 pulses/round, max 6000 RPM. 
Table 2 test engine parameters (BASF)

\begin{tabular}{|c|c|}
\hline Description & Value \\
\hline Model & BASF Prufmotor 368/64, (1964) \\
\hline Bore $[\mathrm{mm}]$ & 65 \\
\hline Stroke $[\mathrm{mm}]$ & 100 \\
\hline Displacement $[\mathrm{ccm}]$ & 332 \\
\hline Maximum power at full load and 600 RPM [kW] & 0.6 \\
\hline Maximum power at full load and 900 RPM [kW] & 0.9 \\
\hline Maximum fuel consumption $[g / h]$ at 600 RPM & 400 \\
\hline orifice diameter $[\mathrm{mm}]$ & 0.6 \\
\hline Mixture Heater [W] & 750 \\
\hline Compression ratio & $4: 1$ to $11: 1$ \\
\hline Speed & 600 RPM \\
\hline Ignition & $13 \mathrm{deg}$ BTDC \\
\hline Spark plug & Kistler 65।7BCD \\
\hline Pressure transducer & Kistler 605IB (error $\pm 1 \%$ ) \\
\hline Oil pressure [min.atm] & I \\
\hline Intake air temperature $\left[{ }^{\circ} \mathrm{C}\right]$ & $21 \pm 2$ \\
\hline Cooling temperature $\left[{ }^{\circ} \mathrm{C}\right]$ & 100 \\
\hline Spark advance [deg. btdc] & 26 \\
\hline Spark plug gap [mm] & 0.5 \\
\hline Breaker point gap [mm] & 0.5 \\
\hline Valve clearance, cold: intake valve $[\mathrm{mm}]$ & 0.2 \\
\hline Valve clearance, cold: exhaust valve [mm] & 0.25 \\
\hline
\end{tabular}

Table 3 Single and dual alcohol-gasoline blends for experimental evaluation

\begin{tabular}{|c|c|c|c|c|c|c|c|}
\hline \multicolumn{8}{|l|}{ Single alcohol -gasoline (SAG) } \\
\hline Blend \# & 1 & 2 & 3 & 4 & 5 & 6 & 7 \\
\hline Methanol \% & 10 & 15 & 20 & 25 & 30 & 40 & 80 \\
\hline$C_{\text {tot }}$ & 10 & 15 & 20 & 25 & 30 & 40 & 80 \\
\hline Gasoline \% & 90 & 85 & 80 & 75 & 70 & 60 & 20 \\
\hline Abbrev. & MIO & MI5 & M20 & M25 & M30 & M40 & M80 \\
\hline Calculated Lower heating value (LHVbl(MJ/kg) & 40.75 & 39.68 & 38.60 & 37.47 & 36.44 & 34.34 & 25.34 \\
\hline Air-fuel ratio (A/Fs) & 14.2 & 13.8 & 13.4 & 12.9 & 12.5 & 11.7 & 8.1 \\
\hline \multicolumn{8}{|l|}{ Dual_alcohol-gasoline (DAG) } \\
\hline Blend \# & 8 & 9 & 10 & 11 & 12 & 13 & 14 \\
\hline Methanol-M & 10 & 15 & 20 & 25 & 30 & 40 & 80 \\
\hline Butanol(-nB) & 20 & 25 & 30 & 35 & 20 & 20 & 10 \\
\hline $\mathrm{C}_{\text {tot }}$ & 30 & 40 & 50 & 60 & 50 & 60 & 90 \\
\hline Gasoline & 70 & 60 & 50 & 40 & 50 & 40 & 10 \\
\hline$M-n B$ & $10: 20$ & $15: 25$ & $20: 30$ & $25: 35$ & $30: 20$ & $40 ; 20$ & $80 ; 10$ \\
\hline LHVbl & 38.79 & 37.22 & 35.64 & 34.08 & 34.45 & 32.38 & 24.37 \\
\hline $\mathrm{A} / \mathrm{Fs}$ & 13.4 & 12.8 & 12.2 & 11.5 & 11.7 & 10.8 & 7.8 \\
\hline
\end{tabular}


Exhaust gas is pumped through a pre-sampler (12) (Figure 1) with pipe connection before the three-way catalytic converter (6). In the pre-sampler, the exhaust gas is filtered and passed through to the individual gas analysers $(13,14$, and 15$)$ dedicated to measuring $\mathrm{UHC}, \mathrm{NO}_{x}$ and $\mathrm{CO}$ and so forth. The measured values were displayed on the PC (8) after conversion by means of the (analogue/digital) $\mathrm{A} / \mathrm{D}$ converter. The fuel-mass flow was measured and delivered as described in this section.

The n-butanol alcohol was manufactured by VWR Prolabo (BDH), with $99.99 \%$ purity, and density of Boiling point: $118^{\circ} \mathrm{C}$ (at $101.3 \mathrm{kPa}$ ), melting point: $-89.8^{\circ} \mathrm{C}$, and flash point: $30^{\circ} \mathrm{C}$. The methanol had purity of $99.9 \%$, and was manufactured by Molar Chemicals (KFT 1151 Budapest). It has density of $790 \mathrm{~kg} / \mathrm{m}^{3}\left(20^{\circ} \mathrm{C}\right)$, water content of $0.028 \%$, and evaporation residual: $0.0008 \%$. The characteristics of diesel used for the experiments was: D2, standard EN 590, CN, $\geq 51$, sulphur content $\leq 10 \mathrm{mg} / \mathrm{kg}$; water content $\leq 200 \mathrm{mg} / \mathrm{kg}$; and kinematic viscosity 2.00 to $4.5\left(\mathrm{~mm}^{2} / \mathrm{s}\right)$ at $40^{\circ} \mathrm{C}$, specific density at $15^{\circ} \mathrm{C}, \geq 0.82$; and flash point of $>55^{\circ} \mathrm{C}$. Gasoline was manufactured by MOL with a specification of EN-228 of octane number 95 .

The aim of this study was to determine the combustion and emissions characteristics of alcohol-gasoline blends fired in the BASF octane rating, single-cylinder, SI, engine illustrated in figure 1. The effect of methanol added to gasoline was initially compared with a study by others; ${ }^{22}$ thereafter the effect of n-butanol on methanolgasoline was determined. The engine was warmed up during a 20 minutes run. The blends were evaluated in terms of indicated pressure and heat release rate (HRR) with respect to Crank angle Degrees (CAD); whereas emission characteristics were evaluated in terms of excess-air ratio $(\lambda)$ at a constant speed of 600 RPM. The HRR was calculated using the indicated pressure data from the engine runs and computer software, COMBI-PC (SMEtech $\mathrm{GmbH}$ ). The blends were prepared by an in-tank blending method (using standard laboratory glassware) a few minutes before testing in the spark ignition engines. The blends in shared volume percentage used are indicated in Table 4.

\section{Results and discussions}

\section{Peak pressure and combustion characteristics}

Figure 3 illustrates the effect of single alcohol gasoline,(SAG):methanol-gasoline blends and dual alcohol gasoline (DAG): n-butanol additive to methanol-gasoline blends on indicated pressure (IP) and heat release rate (HRR).

The ignition delay and the combustion duration are defined as the crank angle from the spark event to $10 \%$ and from $10 \%$ to $90 \%$ cumulative heat release respectively. It was observed that the combustion duration was shorter for M80 (steeper curve of HRR) and therefore the peak of HRR or advance crank angles for M80 was closer to TDC than those for M20 and M10. The authors in this study used a single cylinder, carburetor fuel delivery system with operating speeds of 300 RPM at $(K)$ 1.1. In studies by others ${ }^{22}$ the combustion duration is advanced by 6 degrees with reference to that of gasoline attributed to the fast laminar speed propagation of methanol. The blends studied were M10 (10\% methanol, 90\% gasoline fuel by volume), M20 and M85 where the advance crank angles for M85 was closer to TDC than M20 and M10. The operating condition and the engine types used for the cited work is a three cylinder port injection engine and speed 3000 RPM. The comparison between the cited study and this study confirms the results obtained of the effect of methanol-gasoline on the combustion duration. The peak pressure increases with the methanol fraction in the blend with gasoline. Comparing the HRR curve for $30 \%$ n-butanol additive to $20 \%$ methanol-gasoline: M20:30 with the curve of 20\% methanol-gasoline: M20 indicates a steeper curve for M20:30 than M20 proving that addition of n-butanol to methanolgasoline reduces combustion duration.
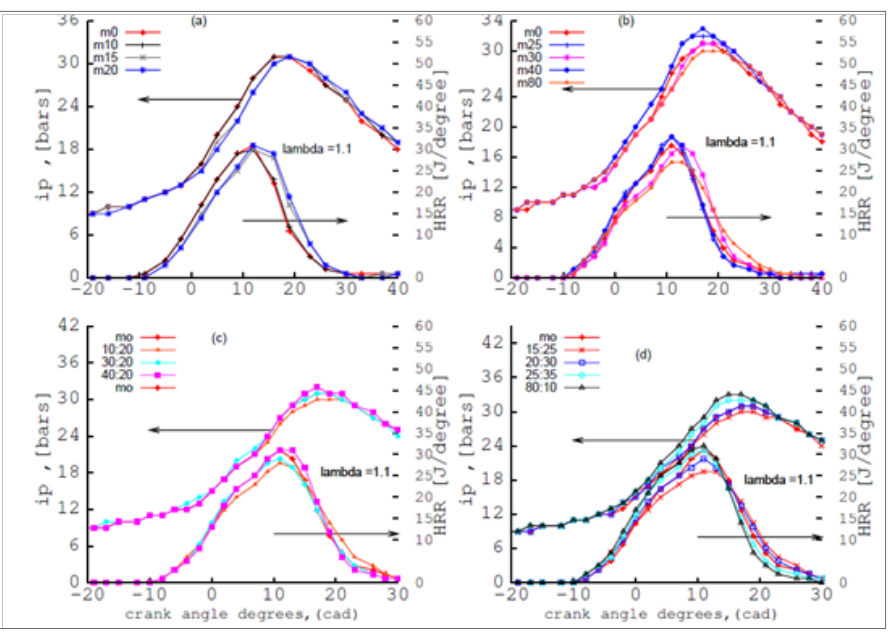

Figure 3 effect of SAG (A, B) and effect of DAG (C, D) blends on mean indicated pressure (IP) and heat release rate (HRR) at $\lambda=1$.I

Figure 4 depicts the effect of the blends at stoichiometric conditions at $(K)=1.0$. The effect of lambda $(K)$ from 1.1 to 1.0 improves the combustion process in the engine because of the stoichiometric conditions attained at lambda 1.0. However, heat release rate, (HRR) is sensitive to the addition of $\mathrm{n}$-butanol to methanol-gasoline blends. The heat release and the combustion efficiency increases with the fraction of n-butanol added to methanol-gasoline blend. Combustion efficiency is given by the formula: brake thermal efficiency (BTE) is $1 /(\mathrm{BSFC} * \mathrm{LHV})$ where BSFC is Brake Specific Fuel Consumption and LHV is Lower Heating Value. The $30 \%$ by volume of n-butanol produces a lower BSFC than M30; ${ }^{21}$ less fuel is burned when a higher carbon-content alcohol such as n-butanol-gasoline blend increases the heating value of the blend. ${ }^{23}$

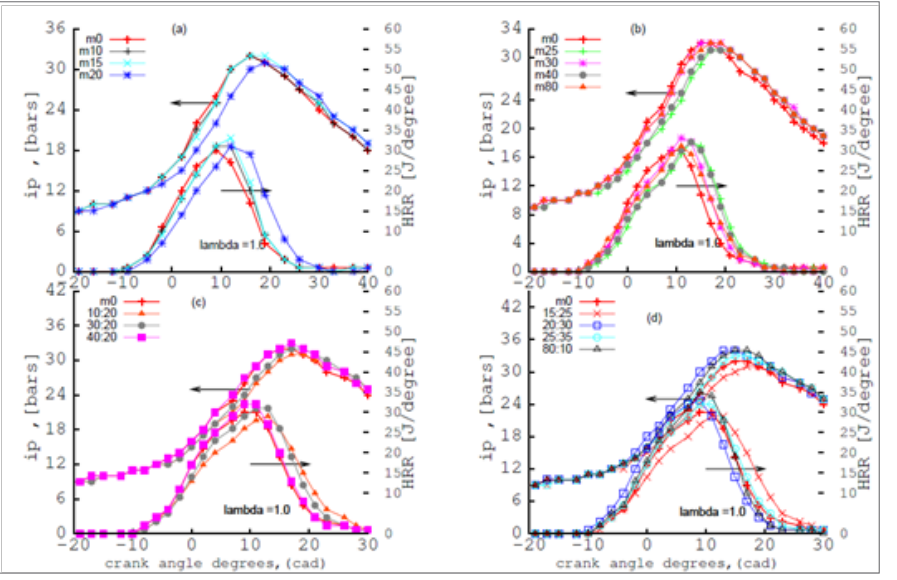

Figure 4 effect of SAG (A, B) and DAG(C, D) blends on mean indicated pressure (IP) and heat release rate (HRR) at $\lambda=1.0$.

Source ${ }^{23}$ 


\section{Emission characteristics}

\section{Unburned hydrocarbon (UHC)}

Unburned hydrocarbons are pollutants that result from inadequate combustion of fuel-air mixture. A layer of UHC is left behind when cold surfaces of cylinder walls of the combustion chamber quench the flame. Similar UHC emission layer develops when UHC fuel-mixture escapes the primary combustion process filling crevices (because of flame quenching at the entrance of these crevices). ${ }^{24}$

Figure 5 indicates the effect of $20 \%$ n-butanol fraction added to M10, or (M10:20) on the emission of unburned hydrocarbon (UHC). The blends do not require any engine modification. The UHC emission increases with n-butanol addition for M10 as the excessair ratio $(K)$ is also increased above 1.1. However, at stoichiometric condition or minimum excess-air: from $7 \%$ up to about $11 \%$, the addition of n-butanol to M10 reduces the UHC emission. As the fuel-air mixture is weakened, through the addition of n-butanol to the methanol-gasoline blend, the oxygen concentration increase, thus absorbing energy as diluents thereby reducing the temperature of the mixture. ${ }^{3}$ this in turn causes a reduction of temperature along the walls of the cylinders resulting in flame quenching and increasing UHC emission. At stoichiometric condition the improved combustion efficiency of the fuel blend reduces the occurrence of flame quenching and therefore reduces UHC emission.

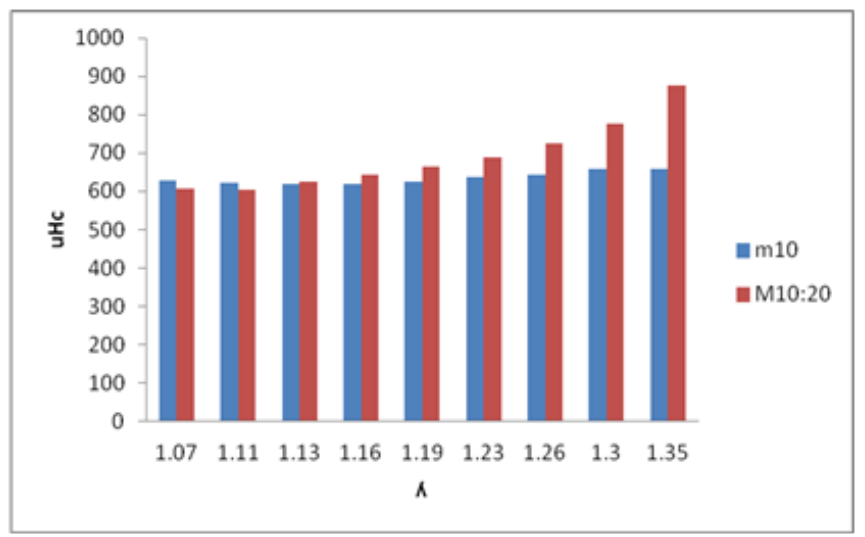

Figure 5 effect of $20 \%$ n-butanol additive to MIO on (UHC) in ppm.

In Figure 6 the addition of $30 \%$ n-butanol to $\mathrm{m} 20$ causes a reduction of UHC emission between 5\% and 26\% excess air. Experiments show that the higher the total alcohol content in the blend the lower the $\mathrm{UHC}$ emission. The increased n-butanol fraction in the blend reduces the in-cylinder temperature while the engine runs at steady state and prolongs or slows the overall combustion rate expecting that the UHC emission level would increase. However, higher combustion efficiency occasioned by raising n-butanol content in the blend causes UHC emission to reduce more than it does with methanol-gasoline blends. The overall UHC emission for M20:30 lie between 500 and $600 \mathrm{ppm}$, which is lower than that of M10:20 which lie between 600 and $800 \mathrm{ppm}$. In Figure 7 the UHC emissions reduce by using m 80 to about $300 \mathrm{ppm}$ and reduce even further by adding $10 \% \mathrm{n}$-butanol to $\mathrm{m} 80$ proving that $\mathrm{n}$-butanol has the effect of moderately reducing UHC emissions above $20 \%$ methanol in the blend. However, the reduced energy density of M80:10 and cost implications may not probably favor its wide use.

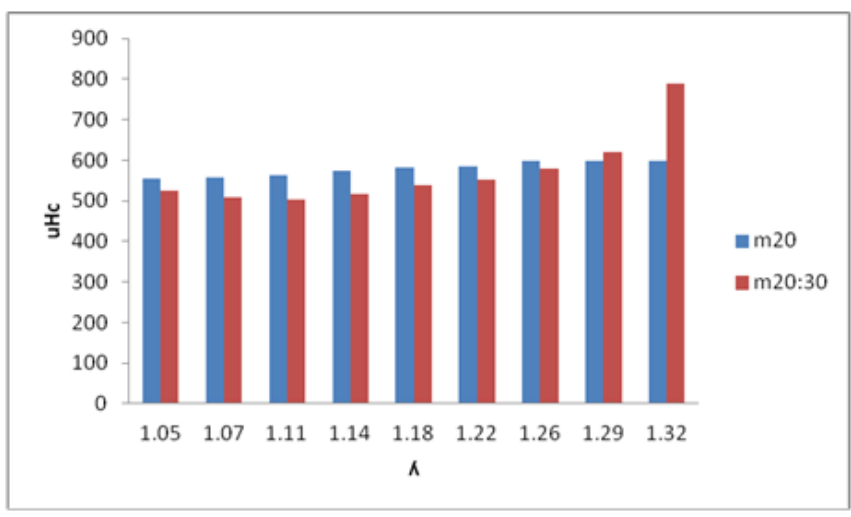

Figure 6 effect of $30 \%$ n-butanol additive to M20 on (UHC) in ppm.

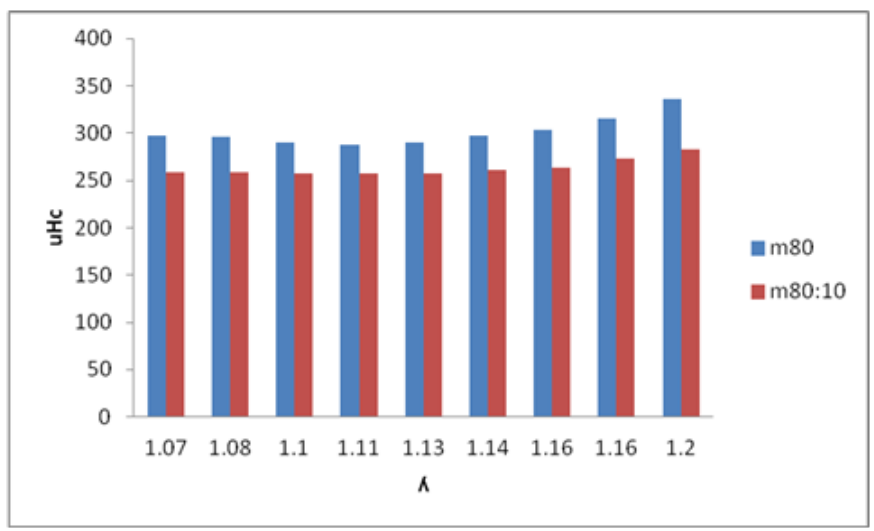

Figure 7 effect of $10 \%$ n-butanol additive to M80 on UHC in [ppm].

\section{Nox emission}

Thermal $\mathrm{NO}_{\mathrm{x}}$ is a by-product of combustion, and its exponential formation rate is dependent on temperature. Thermal $\mathrm{NO}_{\mathrm{x}}$ formation, which is well studied and understood, ${ }^{25}$ depends upon the residence time and higher temperatures. The peak emission of $\mathrm{NO}_{\mathrm{x}}$ for test fuels occurs at approximately: $\lambda=1.1$. This means that its formation is more probable at very high temperatures as a function of heat release.

Figure 8 illustrates the emission of $\mathrm{NO}_{x}$ for the blends $\mathrm{m} 10$ and m10:20. The effect of $20 \%$ n-butanol additive to $\mathrm{m} 10$ on $\mathrm{NO}_{x}$ emission shows a fall in the Nox emission concentration due to the drop in temperatures by the addition of n-butanol. The fuel n-butanol has a high latent heat of evaporation being an alcohol which causes evaporative cooling within the combustion chamber thereby limiting the formation of $\mathrm{NO}_{x}$. As $30 \%$ of $n$-butanol is added to $\mathrm{m} 20$ the profile obtained is shown in Figure 9. It is observed generally that $\mathrm{NO}_{x}$ concentration does not change much when comparing values with the blends m10 and M10:20 near stoichiometric condition. In one study by the authors it was reported that the combustion rate $^{26}$ for blends of n-butanol and methanol-gasoline are slower than methanol-gasoline blends, causing an accumulation of heat release into the expansion and exhaust strokes and raising the cylinder temperatures enough to increase $\mathrm{NO}_{\mathrm{x}}$ concentration. However, due to interference caused by energy absorption by oxygen dilution from $n$-butanol, the temperature threshold is not reached for the formation of thermal $\mathrm{NO}_{x}$. The general explanation is that the high latent heat of evaporation in alcohols results in an evaporative cooling of the mixture. This lowers the 
temperature in the cylinder. Because of this any increase in the alcohol percentage of the fuel mixture causes $\mathrm{NO}_{\mathrm{x}}$ to drop. Therefore, Nox emission did not change much even when $30 \%$ n-butanol was added to $\mathrm{m} 20$. Figure 10 indicates $\mathrm{NO}_{\mathrm{x}}$ emission reduces from $3500 \mathrm{ppm}$

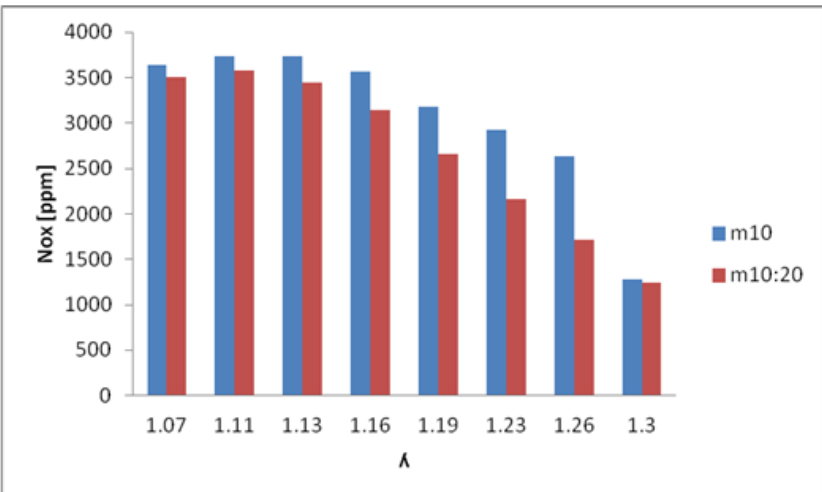

Figure 8 effect of $20 \%$ n-butanol additive to MIO on Nox emission.

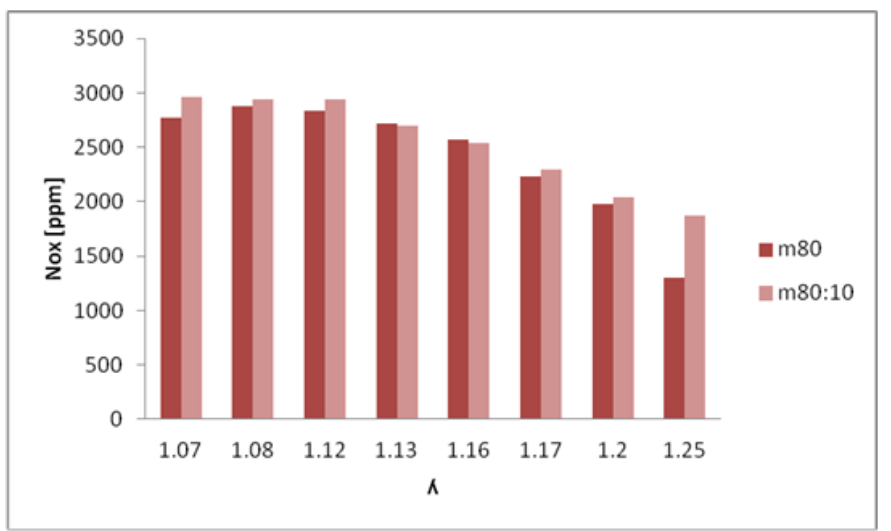

Figure 10 effect of $10 \%$ n-butanol additive to $M 80$ on Nox emission.

\section{Conclusion}

The study was made on a single cylinder spark ignition engine to determine the effect of $n$-butanol additive to a blend of methanolgasoline of combustion and emission characteristics. The combustion duration reduces with increased shared volume of total alcohols in the methanol-butanol-gasoline blends. The peak pressure increases with the methanol fraction in the blend with gasoline. Unburned hydrocarbon (UHC) emissions reduce with $\mathrm{m} 80$ to about $300 \mathrm{ppm}$ and reduce even further with $10 \% \mathrm{n}$-butanol added to $\mathrm{m} 80$ proving that n-butanol has the effect of moderately reducing UHC emissions when methanol fraction is above $20 \%$ in gasoline. As n-butanol is increased further by $30 \%$ additive to $\mathrm{m} 20$ : (methanol $20 \%$ by volume and gasoline $80 \%$ ), $\mathrm{NO}_{\mathrm{x}}$ concentration does not change significantly when comparing values with the blends of $\mathrm{m} 10, \mathrm{M} 10: 20$ (10\% methanol, 30 $\%$ n-butanol 70\% gasoline) and M20:30. In order to reduce emissions in spark ignition engine the suitable blend would be M80:10. However, the Lower heating value is prohibitively low whereby the power output from the engine would be affected. Therefore a compromise would be to select m20:30 which would improve the performance in the spark ignition engine at the set conditions given in the study. for $\mathrm{m} 10: 20$ and $\mathrm{m} 20: 30$ blends to about 3000 for the $\mathrm{m} 80: 10$ blends near stoichiometric condition or for 7 to $11 \%$ excess air. Besides, the shortened combustion rate of blends of methanol-gasoline diminishes the emission of Nox

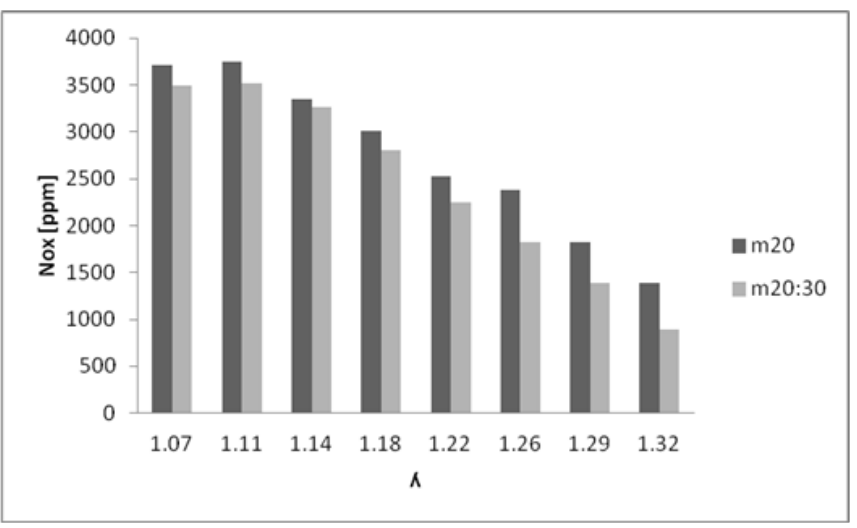

Figure 9 effect of $30 \%$ n-butanol additive to M20 on Nox emission.

\section{Acknowledgements}

This study was made possible through the collaboration between Hungary/South Africa Funding (UID 72384) and NRF the two facilitating universities: Tshwane University of Technology, Pretoria, South Africa and Budapest University of Technology and Economics, Budapest, Hungary; and the latter, made available the laboratory facility, Jendrassik Gyorgy Hotechnikai Laboratorium in Budapest BME where the engine experiments were conducted.

\section{Conflict of interest}

The author declares that there is no conflict of interest.

\section{References}

1. Szwaja S, JD Naber. Combustion of n-butanol in a spark-ignition IC engine. Fuel. 2010;89(7):1573-1582.

2. Alasfour FN. NOx emission from a spark ignition engine using $30 \%$ iso-butanol"gasoline blend: part 2"ignition timing. Applied Thermal Engineering. 1998;18(8):609-618.

3. Alasfour FN, Butanol. A single cylinder engine study:engine performance. International Journal of Energy Research. 1997;21:21-30.

4. Eastop TD, A McConkey. Applied thermodynamics for engineering technologists. $5^{\text {th }}$ ed. England: Pearson Prentice hall; 1993.

5. Giri NK. Automobile technology. Delhi: Khana publishers; 2004.

6. Rakopoulos DC. Rakopoulos CD, Hountalas DT, et al. Investigation of the performance and emissions of bus engine operating on butanol/diesel fuel blends. Fuel. 2010;89(10):2781-2790.

7. Lu X, Zheng Yang, Xiaoxin Zhou, et al. Auto-ignition and combustion characteristics of n-butanol triggered by low- and high-temperature reactions of premixed n-heptane. Fuel. 2013;112:1-7.

8. Dernotte J, C Mounaim Rousselle, F Halter, et al. Evaluation of ButanolGasoline Blends in a Port Fuel-injection, Spark-Ignition Engine. Oil Gas Sci Technol Rev IFP. 2010;65(2):345-351.

9. Pukalskas S, Zenonas Bogdanovičius, Egle Sendžikiene, et al. The Mixture of biobutanol and Petrol for Otto Engines. Transport. 2009;24(4):301-307. 
10. D'urre P. Fermentative butanol production Bulk chemical and biofuel. Ann N Y Acad Sci. 2008;1125:353-362.

11. Singliar M, Dolnak M. Emerging Technologies for second generation of biofuels. MOL scientific Magazine. 2008;67-80.

12. Eyidogan M, Ahmet Necati O, MustafaCanakci, et al. Impact of alcoholgasoline fuel blends on the performance and combustion characteristics of an SI engine. Fuel. 2010;89(10):2713-2720.

13. Gu X, Zuohua Huang, JianCai, et al. Emission characteristics of a sparkignition engine fuelled with gasoline-n-butanol blends in combination with EGR. Fuel. 2012;93(2012):611-617.

14. Najafi G, B Ghobadiana, T Tavakoli et al. Performance and exhaus emissions of a gasoline engine with ethanol blended gasoline fuels using artificial neural network. Applied Energy. 2009;86(5):630-639.

15. Zhang Y, Boehman AL. Oxidation of 1-butanol and a mixture of n-heptane/1-butanol in a motored engine. Combustion and Flame. 2010;157:1816-1824.

16. Broustail G, F Halter, P Seers, et al. Experimental determination of laminar burning velocity for butanol and ethanol iso-octane blends. Fuel. 2011;90(1):1-6.

17. Sayin C. Engine performance and exhaust gas emissions of methanol and ethanol-diesel blends. Fuel. 2010;89(11):3410-3415.

18. Shanghua RC, Clemente RC, Hu Tiegang, et al. Study of spark ignition engine fueled with methanol/gasoline fuel blends. Applied Thermal Engineering. 2007;27:1904-1910.
19. Said AF. Effect of initial temperature on burning velocity of methanol and ethanol -air mixtures. Engineering and applied sciences. 2012;7(10):13071313.

20. Yao M, Hu wang, Zunqing zhenge, et al. Experimental study of n-butanol additive and multi-injection on $\mathrm{HD}$ diesel engine performance and emissions. Fuel. 2010;89(9):2191-2201.

21. Alasfour FN. Butanol--a single-cylinder engine study: availability analysis. Applied thermal engineering. 1997;17(6):537-549.

22. Yanju W, Liu Shenghua, Li Hongsong, et al. Effects of methanol / gasoline blends on a spark ignition engine performance and emissions. energy\&Fuels. 2008;22:1254-1259.

23. kyprianidis KG. Developments in Combustion Technology. Rijeka: Intech; 2016.

24. Heywood JB. Internal combustion engine fundamentals. New York: McGraw-Hill; 1988.

25. Raslavicius L, Z Bazaras. Variations in oxygenated blend composition to meet energy and combustion characteristics very similar to the diesel fuel. Fuel Processing Technology. 2010;91(9):1049-1054.

26. Siwale L, Kristóf L, Bereczky A, et al. Performance, Combustion and Emission Characteristics of N-Butanol Additive in Methanol-Gasoline Blend Fired in a Naturally-Aspirated Spark Ignition Engine. Fuel Processing Technology. 2014;118:318-326. 